\title{
Design and performance analysis of a parabolic trough power plant under the climatological conditions of Tamanrasset, Algeria
}

\author{
D. E. Benhadji Serradj ${ }^{1,2} \cdot$ A. B. Sebitosi ${ }^{3} \cdot$ S. O. Fadlallah ${ }^{2}$
}

Received: 21 August 2020 / Revised: 24 February 2021 / Accepted: 22 April 2021 / Published online: 8 May 2021

(c) Islamic Azad University (IAU) 2021

\begin{abstract}
Algeria's energy demands are tremendously growing, and on the African continent it ranks among the countries with the highest energy consumption. To counter its growing energy demand, the country is progressively adopting renewable energy technologies, although conventional energy technologies still play a central role in its electricity production. The huge solar energy potential in Algeria can be exploited and utilized to meet the country's growing energy demand with minimal greenhouse gas production. Given that concentrating solar power is viewed as one of the most promising alternatives in the field of solar energy utilization, this study investigates the viability of a $100 \mathrm{MW}$ parabolic troughbased power plant at Tamanrasset, Algeria. The plant was simulated in the System Advisor Model software considering the actual electricity load profile of the targeted location and implementing two different condenser types: evaporative and air-cooled. By comparing the plant's electricity production to the city's real load, the plant was in position of supplying about $78 \%$ and $60 \%$ of the city's electricity demand during the winter and summer seasons, respectively. The results show that implementation of such CSP plants could play an important role in meeting the energy demand as well as mitigating climate change through greenhouse emissions avoided in electricity generation process.
\end{abstract}

Keywords Concentrating solar power $\cdot$ Parabolic trough $\cdot$ Meteonorm $\cdot$ SAM (System Advisor Model) $\cdot$ Algeria

\section{Introduction}

Algeria's economy is mainly reliant on exportation of oil, and with the prevailing drop in fossil fuel prices due to COVID-19 pandemic as well as the global economic recession (Yoshino et al. 2020), the economy has been negatively affected. Currently, government is considering austerity measures in order to mitigate fiscal pressure and a possibility of budget deficit (US Energy Information

Editorial responsibility: Samareh Mirkia.

S. O. Fadlallah

Sulaiman.fadlallah@aut.ac.nz

1 Department of Energy Engineering, Institute of Water and Energy Sciences (Incl. Climate Change), PAN African University, Tlemcen, Algeria

2 Department of Mechanical Engineering, Auckland University of Technology, Auckland, New Zealand

3 Solar Thermal Energy Research Group, Department of Mechanical and Mechatronics Engineering, Stellenbosch University, Stellenbosch, South Africa
Administration (EIA) 2021). The government has several subsidy policies in place, for instance, because of electricity subsidies, electricity tariffs are at 0.04 USD\$/ $\mathrm{kWh}$, which ranks as one of the lowest rates worldwide (GlobalPetrolPrices.com 2020). Given the very low electricity tariffs in the country, there is no energy consumption discipline among the citizens which is depicted by an annual energy consumption of about $1302.22 \mathrm{kWh}$ per capita, ranked among the highest consumption on the continent, whose average consumption is $587.08 \mathrm{kWh}$ per capita (IndexMundi 2021).

As one of the leading fossil fuels exporting countries, on a daily basis crude oil and natural gas in the excess of 1.4 million barrels 86.5 billion cubic meters are produced, respectively, with about $85 \%$ and $70 \%$ exported mainly to Europe. With the rapid growth of the population, rural-urban exodus and constant growth of the economy, energy demand was estimated as likely to double between 2012 and 2021 (Stambouli et al. 2012). Since conventional energy resources are non-replenishable, reliance on such resources could result in energy insecurity as their sources run out. With Algeria's energy consumption 
increment forecast at about $53 \%$, its current conventional energy resource reservoirs are predicted to adequately sustain the country's electricity generation for about 50 years (Stambouli et al. 2012). As a possible alternative measure of addressing the electricity security of the country, adoption of renewable energy technologies is inevitable. Solar energy resource, for both photovoltaic and concentrated solar power technologies, is by far the most abundant resource of all the renewable energy resources that Algeria is endowed with (Schnatbaum 2009; Kabir et al. 2018).

Of the countries in the Northern African region, Algeria is strategically located in the sun belt coordinates $18.96^{\circ} \mathrm{N}-37.09^{\circ} \mathrm{N}$ and $8.68^{\circ} \mathrm{W}-11.96^{\circ} \mathrm{E}$ (Yaiche et al. 2014). The Sahara Desert covers about $86 \%$ of the country's 2.381 million $\mathrm{km}^{2}$, reported to have about $1,787,000$ $\mathrm{km}^{2}$ area that is suitable for CSP generation (Abbas et al. 2011). Solar energy potential variation across the country is evident. For instance, the northern (coastal) region experiences about 2650 sunshine hours annually, while the southern (Sahara) region experiences about 3500 sunshine hours annually. The Sahara region is characterized by an average 8 sunshine hours daily, that at times goes up to 11 sunshine hours during the summer season (Boudries and Dizene 2008). The daily solar irradiation received over the Algerian territory averages around $4.5 \mathrm{kWh} / \mathrm{m}^{2}$ and $7.26 \mathrm{kWh} / \mathrm{m}^{2}$ for the northern and southern regions, respectively (Boudries and Dizene 2008). Figure 1 shows the mapping of the solar energy potential for Algeria by the Centre de Développement des Energies Renouvelables (CDER). It can be observed that Algeria can exploit the solar energy resource at any location of the country. Literature reports that about a little as $10 \%$ of country's Sahara region can generate enough electricity to meet the demand of the entire Europe (Stambouli et al. 2012).

The received solar radiation from the sun can be utilized to generate electricity either by direct conversion of photons via the photovoltaic effect in photovoltaic (PV) systems or by indirect generation of thermal energy by means of solar thermal systems. Due to relative low unit cost of generation and higher efficiencies of about $35 \%$, solar thermal technologies are perceived as most promising in comparison with solar photovoltaic technologies (Wu et al. 2010; Goswami 2015; Uzair 2018). Concentrating solar power (CSP) systems, which are a direct alternative to the existent fossil fuel thermal based power systems, is categorized as a solar thermal system. CSP plants, with their several types, consist of three main parts. Initially, solar irradiation is concentrated on receivers by means of collector systems, after which the radiation energy is converted into thermal energy in the receiver using heat transfer fluids (HTF). Carrying high-temperature HTF, solar receivers drive the fluid to the power block, where the thermal energy is converted to mechanical energy and subsequently into electrical
Fig. 1 Overall daily solar radiation received in $\mathrm{kWh} / \mathrm{m}^{2}$ (Stambouli et al. 2012)

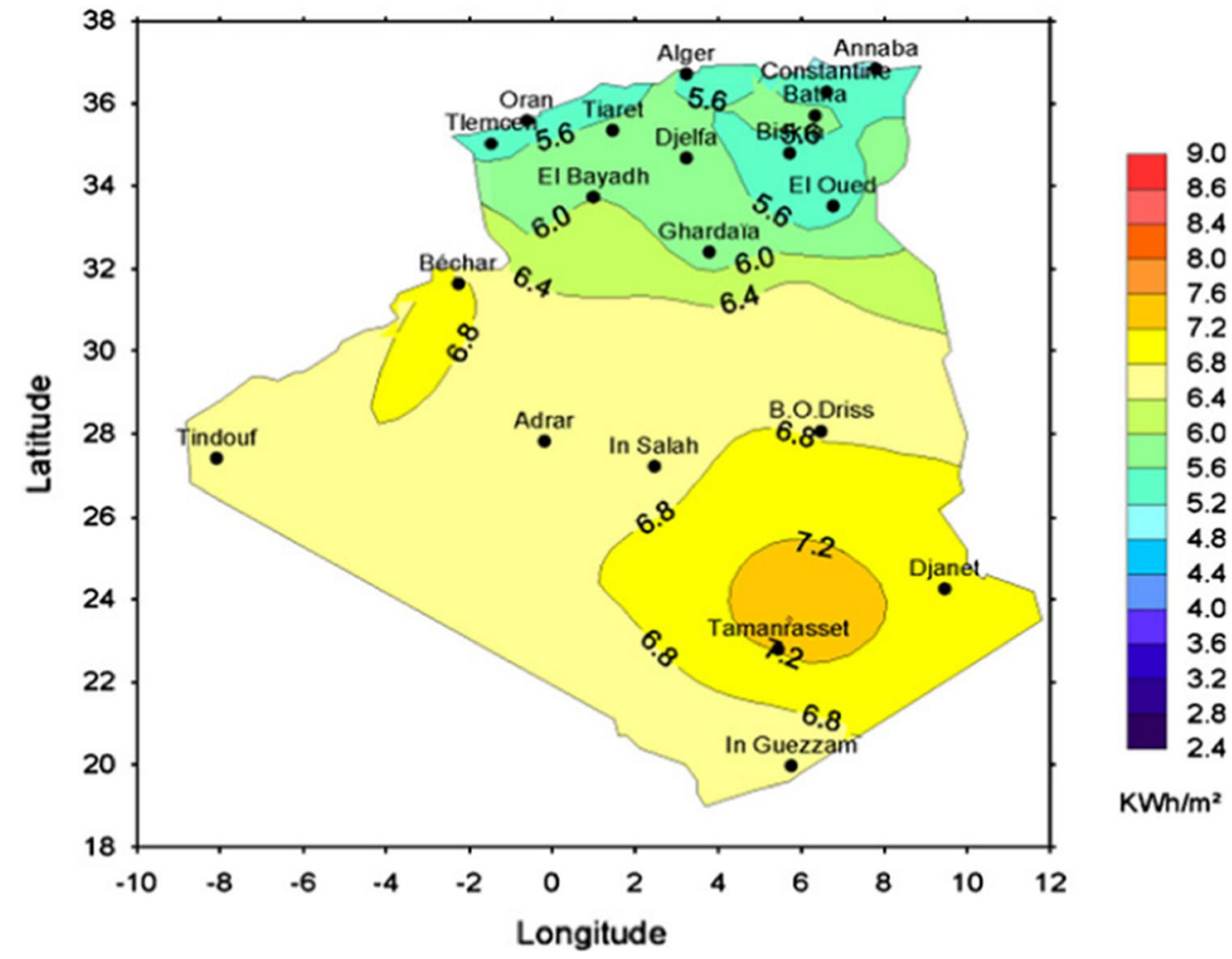


energy, which is fed to the grid (Ummadisingu and Soni 2011; Kaltschmitt et al. 2007).

The CSP technologies include, among others, parabolic dish, parabolic trough, linear Fresnel, and central receiver (tower) technologies. Of all the mentioned CSP technologies, parabolic trough technology has dominated the rest over the last 28 years of commercial operation. Also, parabolic trough technology has the ability of generating electricity either as a stand-alone or in a hybrid system, while maintaining the lowest levelized cost of electricity (LCOE) and at minimal techno-economic risks (Baharoon et al. 2015). With the possibility of hybridization, parabolic trough technology can be incorporated with conventional energy technologies. Utilization of the parabolic trough technology with thermal energy storage (TES) is reported to have resulted in electricity generation unit cost of $0.14 \mathrm{USD} \$ / \mathrm{kWh}$. Currently, the parabolic trough technology is the most widely adopted technology of all the CSP technologies, accounting for about $95 \%$ of commercially existent power plants, representing 2751.41 MWe total installed capacity (Baharoon et al. 2015).

Undertaking a techno-economic viability analysis prior to implementation of any project is crucial in order to have an information decision-making process on whether or not to proceed with the implementation of the project (Tamir 2011). Due to design and sizing inconsistence of power plants that result in improper designs and oversizing, such circumstances affect the investment costs of the project. Thus, appropriate software tools that optimize the designing and sizing of power plants as well as undertaking their economic analysis ought to be adopted (Sinha and Chandel 2014; Fadlallah and Benhadji Serradj 2020). Of the existent software tools, System Advisor Model, also known with the name SAM, stands out distinctively as one of the most extensively utilized software packages for the analysis of CSP plants. The software was developed in 2005 by the National Renewable Energy Laboratory in collaboration with Sandia National Laboratories. In 2007, with the release of the first public version, it was possible for solar energy professionals to evaluate photovoltaic and concentrating solar power systems (Chukwubuikem and Komla 2015). SAM is an open source simulation software which is used by different categories of professionals (project developers, academic researchers, policy makers and manufacturers). Companies use SAM to test and evaluate the performance of their products and their impact on the efficiency or cost reduction of installed systems. The software can also be used to analyze different configurations of a selected technology to maximize the benefits of projects. Policy makers and designers also use the model to experiment with different incentive structures (Chukwubuikem and Komla 2015). The software also offers many financial and economic analyses for energy projects, using as inputs the system lifetime, discount rate, inflation rate, loan amount and loan rate (Chukwubuikem and Komla 2015). The flexibility that SAM delivers has attracted many researchers worldwide in recent years [Lopes et al. 2021 (Portugal); Aseri et al. 2020 (India); Agyekum and Velkin 2020 (Ghana); Bhuiyan et al. 2020 (Bangladesh); Pina et al. 2021 (Spain); Boretti et al. 2020 (Saudi Arabia); Liu et al. 2021 (China)].

Focusing on Algeria, Abbas et al. (2013a, b) utilized SAM to investigate the electricity generation performance as well as the economic analysis of a $100 \mathrm{MW}$ capacity solar parabolic trough power plant considering multiple sites in the country. The study showed that the proposed power plant requires considerable capital investment for its viability. The further recommended an undertaking of a detailed sensitivity analysis in order to identify the conditions that would make the adoption of this technology economically feasible for the implementers with a guarantee of returns on investment (Abbas et al. 2013a, b).

Furthermore, Boukelia et al. (2015) focused on the optimization of two parabolic trough solar thermal power plants of net capacity of $50 \mathrm{MW}$ integrated with thermal energy storage, and fuel backup system. By considering four factors (i.e., energy, environment, exergy, and economy), the study concluded that the presented optimization analysis can be further improved by taking into consideration influential factors such as solar radiation, cooling system technology, and key plant design parameters. Based on a $50 \mathrm{MW}$ capacity CSP power plant intended to be implemented in Hassi R'mel City, in the south of Algeria, Mihoub et al. (2017) proposed a procedure for identifying the best configuration as well as an ideal design to adopt for the future solar thermal power plants setting maximization of their annual power generation and minimization of their LCOE as the methodological objectives.

More recently, Ikhlef and Larbi (2020) have carried out a techno-economic analysis using SAM on the existent Hassi R'mel's solar power plant in the southern region of Algeria. The plant's current configuration comprises $25 \mathrm{MW}$ parabolic trough connected to $130 \mathrm{MW}$ cycle gas turbines. The study adopted a multi-objective optimization approach to identify the desirable conditions and parameters as well as the adoptable optimal design configuration of the power plant maximum power generation in the future. The study findings affirm the role that CSP plants could play in electrifying the countries located in the Middle East and North Africa (MENA) region, particularly Algeria in this case, which has an abundant solar energy resource potential.

Sonelgaz ${ }^{\circledR}$, which is the country's sole electricity generating and distributing company, has ensured that close to $99 \%$ of the country's population has access to 
electricity. Majority of the country's population, approximately $80 \%$, lives in the North (Boukelia and Mecibah 2013). Although the national electrification rate is high, during the summer season which are characterized by high electricity demand, several provinces in the country experience power outages especially in the southern region where temperatures go as high as $45^{\circ} \mathrm{C}$ in summer. Several traders also assert that they record significant losses whenever power outages last to close to $6 \mathrm{~h}$. Some of the challenges highlighted by the electricity distribution company is the aspect of grid network upgrade costs, especially for the lines in the locations deep in the desert because of the long distances and the nature of settlements that scattered.

Given the fact that parabolic trough systems, with their dominance and ability to generate electricity whether as stand-alone or in hybrid systems at the lowest LCOE and with low technical and economic risks, have been widely utilized over the past decades worldwide, and while several studies such as (Abbas et al. 2013a, b; Boukelia et al. 2015; Mihoub et al. 2017; Ikhlef and Larbi 2020) have attempted investigate the possibility of implementing parabolic trough systems in Algeria to ensure a sustainable energy transition, to the knowledge of the authors no study has so far taken into consideration prominent factors such as solar radiation, cooling system technology used, seasonal variations, and other key design parameters in their investigations. Also, these studies in the literature did not consider the actual electricity load profile of the targeted location investigated for the installation of the parabolic trough power plant. To address these existent research gaps, this study undertakes a comprehensive investigation to determine the optimal and appropriate design for a utility-scale parabolic trough-based CSP power plant in the most suitable site in Algeria to meet the country's escalating energy demands. Such thorough investigation will demonstrate that the establishment of such utility-scale parabolic trough power plants can be an important part of the Algerian's strategies not only to add a new capacity but also to increase energy security, addressing the environmental concerns.

\section{Materials and methods}

\section{Site selection and solar resource assessment}

In this study, the province of Tamanrasset (shown in Fig. 2) was considered as the site for implementation of the proposed parabolic trough power plant. Former studies have highlighted that this region is the most favorable site for electricity generation via CSP systems (Abbas

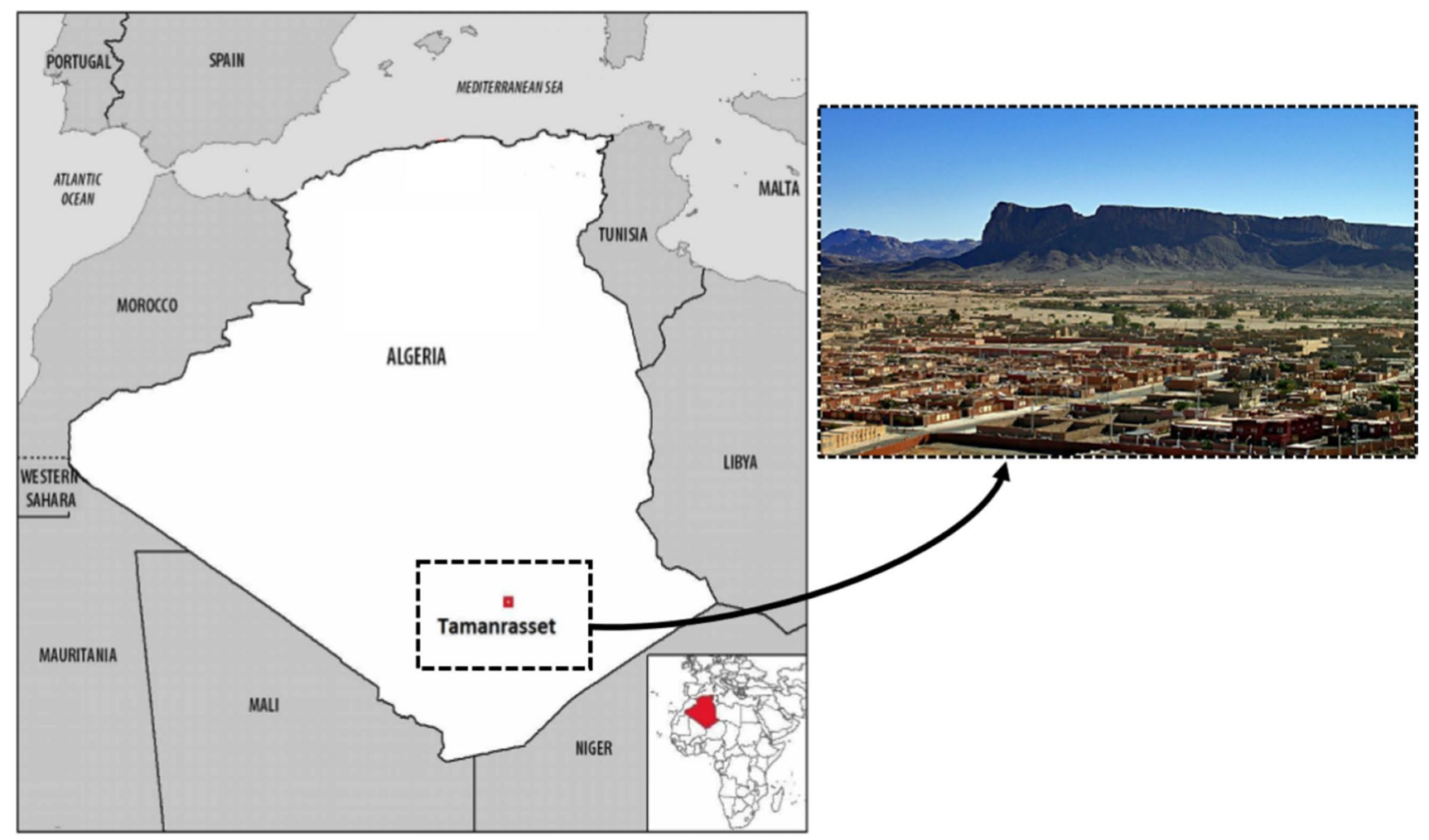

Fig. 2 Location of Tamanrasset on the map 
et al. 2009; 2011; 2014; Stambouli et al. 2012; Boukelia et al. 2015). The city of Tamanrasset receives an annual direct normal irradiation of about $2800 \mathrm{kWh} / \mathrm{m}^{2}$ and a daily average of $7.7 \mathrm{kWh} / \mathrm{m}^{2}$, which is the highest DNI received across the country. Notably, most of the existent CSP plants are in places that on average receive annual DNI less than $5.9 \mathrm{kWh} / \mathrm{m}^{2}$ (ANDI 2013; Abbas et al. 2013a, b).

Tamanrasset, Algeria's biggest province is located on coordinates $22.47^{\circ} \mathrm{N}$ and $5.31^{\circ} \mathrm{E}$. The province is at an altitude of $1377 \mathrm{~m}$ above sea level and covers a surface area of $619,360 \mathrm{~km}^{2}$ and is a home to about 205,220 people. Given its location in the southern region of the country, Tamanrasset experiences longer and hotter summer seasons characterized with daily temperatures averaging at about $30{ }^{\circ} \mathrm{C}$ that sometimes exceed $38^{\circ} \mathrm{C}$ between June and September. With its location in the Sahara Desert, the province is extremely dry throughout the year, reportedly receiving an average annual rainfall of about $43 \mathrm{~mm}$. Also, the province is generally flat and surrounded by massive desert mountains.

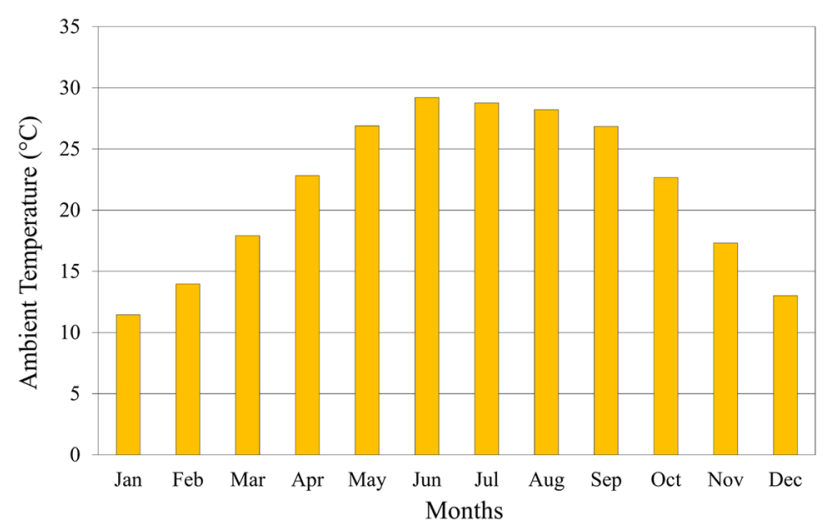

(a) Hourly ambient temperature
Generally, about $90 \%$ of the provinces have access to the main grid which is linked to the $1584 \mathrm{~km}$ transmission lines. However, remote areas of the province rely on stand-alone solar PV system installations for their electricity demands because they do not have access to the main grid. Likewise, access to natural gas lines is restricted to about $11 \%$ in the town of Ain Salah that is located about $665 \mathrm{~km}$ to the north of Tamanrasset province (ANDI 2013).

\section{Site weather data}

For modelling and simulating the parabolic trough power plant, SAM requires meteorological data for the selected location. A Typical Meteorological Year 3 (TMY3) weather file data format was generated from Meteonorm database. The weather file incorporates different hourly measurements for different parameters. It generates data for one year, considered as a typical year because it represents an average of all years where measurements were available (Iliev 2011; Remun et al. 2015). Figure 3 presents the average monthly direct normal irradiation,

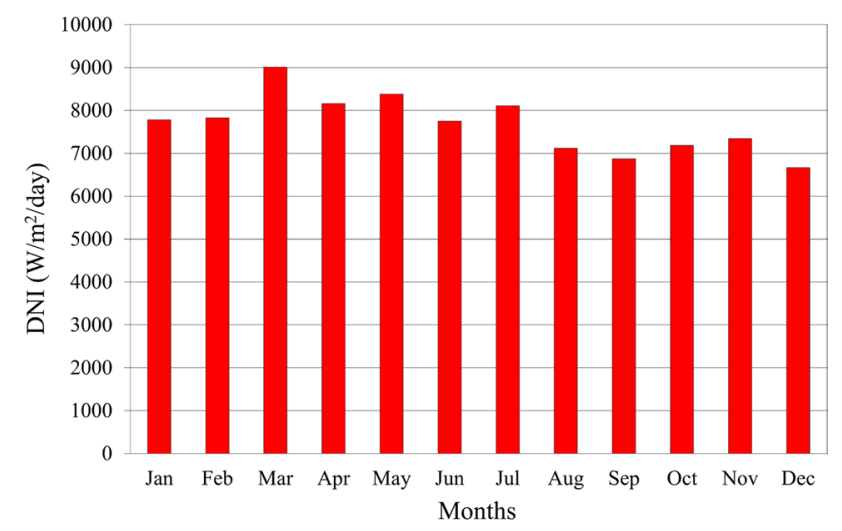

(b) Resource beam normal irradiation

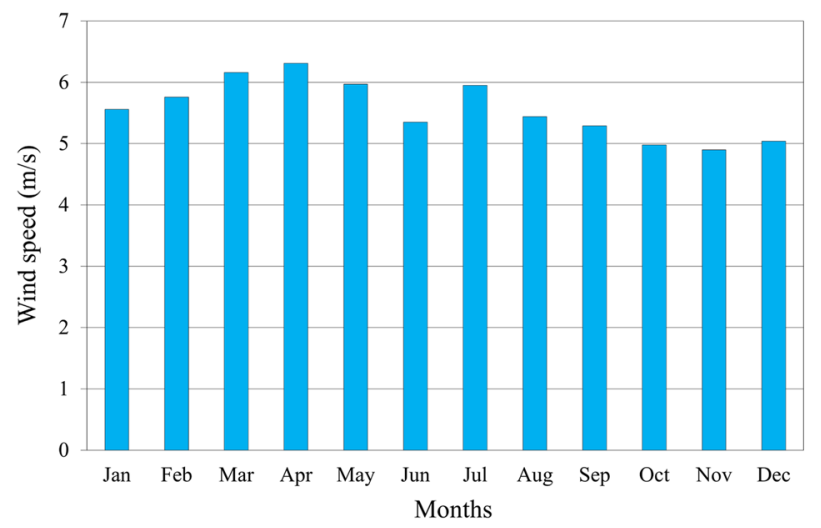

(c) hourly wind speed

Fig. 3 Tamanrasset weather measurements acquired from Meteonorm. a Hourly ambient temperature, b Resource beam normal irradiation, c hourly wind speed 
ambient temperature and wind speed for Tamanrasset city. The Meteonorm database provides estimates of uncertainties depending on the chosen location, and for the case of Tamanrasset city, the following errors in the data measurements were specified:

- Mean irradiance of global radiation horizontal: $3 \%$

- Irradiance of beam: $6 \%$

- Ambient temperature: $0.3{ }^{\circ} \mathrm{C}$

\section{Load profile}

To size the proposed parabolic trough power plant to meet the electricity needs of the population of Tamanrasset, the city's electricity load profile was determined. The electricity demand data for the entire year of 2019 was obtained from the local utility in Tamanrasset city, expressed in Mega-Volt Amperes (MVA) for each 15 min. The apparent power $(S)$ was opted for over the active power $(P)$ in sizing the proposed power plant since the latter is mainly concerned with the distribution part other than the generation part of the electricity system. The relationship between apparent power and active power is shown in Eq. (1).

$P(W)=S(\mathrm{VA}) * \mathrm{PF}$

where $(\mathrm{PF})$ is the system's power factor.

Taking into consideration the weather conditions at the site, utilization of the air conditioning systems by the residents inevitable. Thus, the extreme weather conditions during winter and summer seasons alter the electricity load profile of the city because of very high electricity

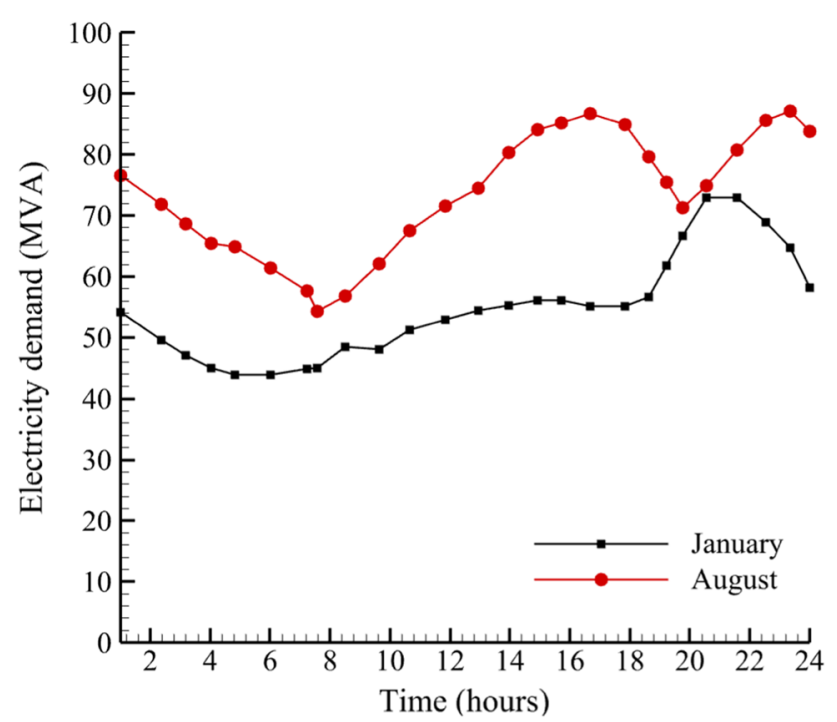

Fig. 4 Tamanrasset load profile demand in these seasons unlike in the other seasons of the year. Figure 4 shows the average daily electricity load demand for the months of January and August for the 2019 in Tamanrasset city. It is evident in Fig. 4 that during the summer season (month of August), the city experiences high electricity demand for the period 13:00-17:00 pm during daytime and for the period 21:00-23:00 pm during the night time. On the contrary, during the winter season (month of January), the city only experiences high electricity demand at night for the period 20:00 pm-midnight. Therefore, considering that the highest electricity demand peaks occur during the summer seasons, the sizing of the proposed power plant in this study was done based on the summer electricity load demand.

\section{Solar field system design and sizing}

A 100 MWe capacity (Net output at design point) parabolic trough power plant that utilizes a steam Rankine cycle was proposed to supply electricity to the existent electricity demand of Tamanrasset city. The choice of this plant combination was based on the literature assertion that parabolic trough power plants with steam Rankine cycles are the most mature and established technology (Desai and Bandyopadhyay 2016). A techno-economic analysis of the proposed power plant was undertaken to ascertain its viability. To determine the solar field dimensions, the SAM software offers the user two approaches. For the first approach, the user specifies the desired solar multiple (the ratio that defines the capacity of the thermal power plant to deliver energy during cloudy days) to use and the software determines the rest of the parameters such as the number of parabolic collectors and number of loops. For the second approach, the user specifies the number of parabolic collectors and the software determines the rest of the parameters such as solar multiple and number of loops. In this study, the latter approach of the software was used.

The used number of collectors for the solar field was evaluated based on the required thermal output and the electricity load demand. The inlet and outlet temperatures of the heat transfer fluid (HTF) across the solar field loops was set by the users in the SAM software. The SAM software includes a package with several commercially available HTFs and likewise offers liberty to the user to define new properties of the HTF that is not included in the software. Therminol VP-1 was utilized as the HTF in the proposed power plant in this study because of its low freezing point that result in minimal electricity consumption by the power plant required to keep the HTF in a liquid state. Table 1 shows the key properties 
Table 1 Therminol VP-1 properties

\begin{tabular}{llllll}
\hline Name & Type & $\begin{array}{l}\text { Minimum operating } \\
\text { temperature }\left({ }^{\circ} \mathrm{C}\right)\end{array}$ & $\begin{array}{l}\text { Maximum operating } \\
\text { temperature }\left({ }^{\circ} \mathrm{C}\right)\end{array}$ & Freeze point & Comment \\
\hline Therminol VP-1 & $\begin{array}{c}\text { Mixture of biphenyl and } \\
\text { diphenyl oxide }\end{array}$ & 12 & 400 & $\begin{array}{c}12{ }^{\circ} \mathrm{C} \text { (crystallization } \\
\text { point) }\end{array}$ & $\begin{array}{c}\text { Standard for current } \\
\text { generation oil HTF } \\
\text { systems }\end{array}$ \\
\hline
\end{tabular}

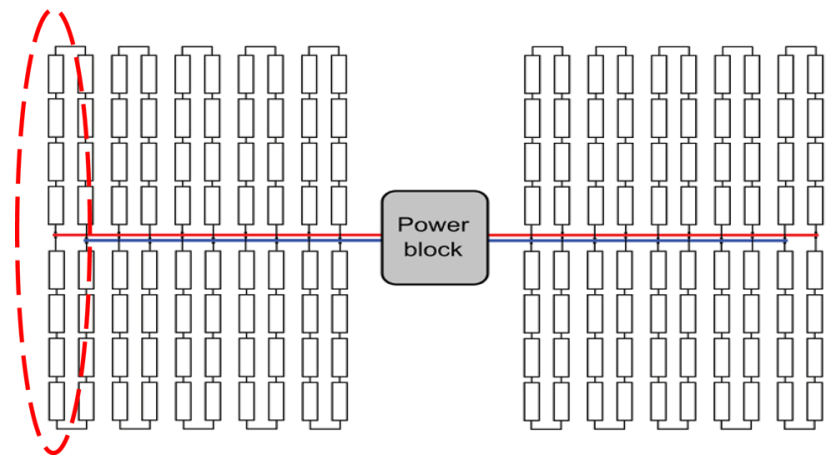

Fig. 5 Solar field alignment (Kariuki 2012)

of Therminol VP-1 relevant for its use as the HTF in the solar field loops of a power plant.

A solar field comprises several loops, where by each loop constitutes of a couple of solar collectors, as shown in Fig. 5. The required number of loops and their composition is reliant on the thermal energy demand of the designed power block. The desire type of solar collector and receiver to be used in the designing of the plant can be selected from SAM's library. The choice of solar collector and receiver utilized in this study was based on their cost and technical performance in comparison with other alternatives as discussed (Wagner and Gilman 2011). The characteristics of the selected solar collector and receiver used in this study are presented in Table 2 (Geyer et al. 2002; Schott Solar 2013). To achieve a solar multiple of 2 as well as meeting the thermal energy demand of the power block, the solar field sized to have 146 loops with a reflective area of $954,840 \mathrm{~m}^{2}$.

The thermal energy generation performance of the solar field is influenced mainly by the amount of direct normal irradiance (DNI) received, the velocity at which the HTF enter the solar field $\left(V_{\mathrm{HTF}}\right)$, the ambient temperature $\left(T_{\mathrm{amb}}\right)$, the wind speed at the location as well as the other parameters provided in the weather file (Kost et al.

Table 2 Parabolic trough collector and the heat collector receiver characteristics

Euro trough ET 150 characteristics

\begin{tabular}{|c|c|}
\hline Parameter & Value \\
\hline Focal Length & $1.71 \mathrm{~m}$ \\
\hline Absorber Radius & $3.5 \mathrm{~cm}$ \\
\hline Aperture Width & $5.77 \mathrm{~m}$ \\
\hline Aperture Area & $817.5 \mathrm{~m}^{2}$ \\
\hline Collector Length & $148.5 \mathrm{~m}$ \\
\hline Number of Modules per Drive & 12 \\
\hline Number of Absorber Tubes & 36 \\
\hline Mirror reflectivity & $94 \%$ \\
\hline Weight of steel structure and pylons, per $\mathrm{m}^{2}$ aperture area & $18.5 \mathrm{~kg}$ \\
\hline \multicolumn{2}{|l|}{ Schott PTR 70 Receiver characteristics } \\
\hline Parameter & Value \\
\hline Length & $4.060 \mathrm{~m}$ \\
\hline Outer diameter & $70 \mathrm{~mm}$ \\
\hline Solar absorptance & 0.95 \\
\hline \multirow[t]{4}{*}{ Glass envelope } & Borosilicate glass \\
\hline & Outer diameter $125 \mathrm{~mm}$ \\
\hline & Antireflective coating \\
\hline & Solar transmittance: $\tau \geq 97 \%$ \\
\hline Operating pressure & $\leq 41$ bar (Absolute $)$ \\
\hline
\end{tabular}




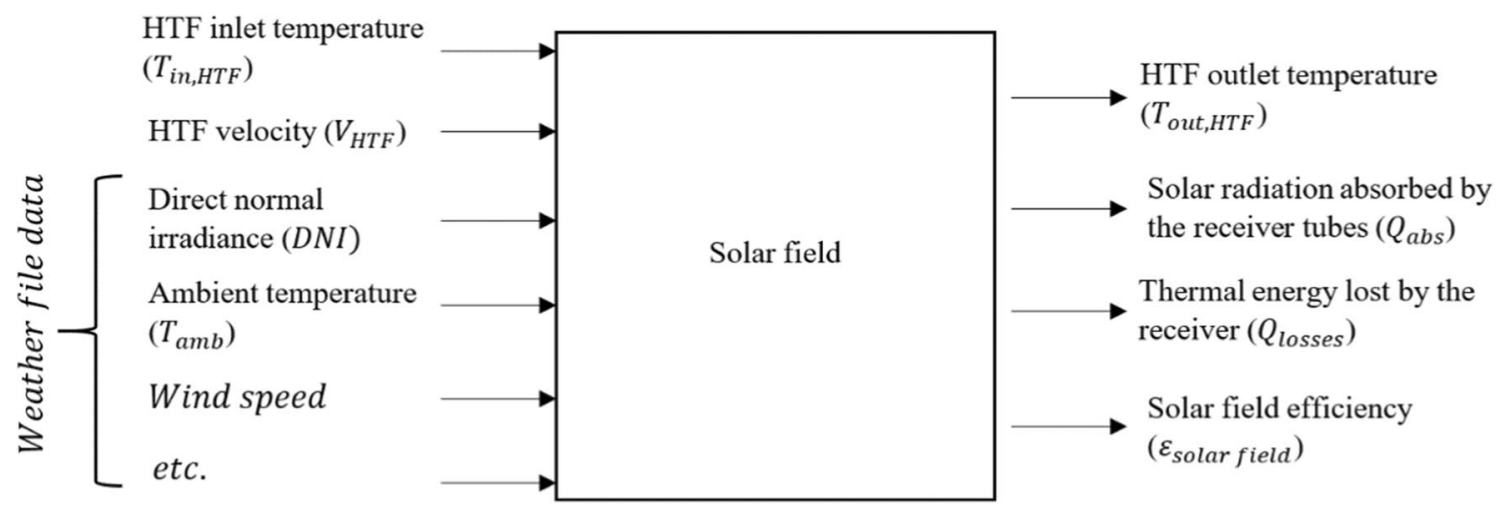

Fig. 6 Flow of information in the solar field

Table 3 Power cycle system configuration

\begin{tabular}{ll}
\hline Parameter & Value \\
\hline Plant capacity & \\
Design gross output & $111 \mathrm{MWe}$ \\
Estimated gross to net conversion factor & 0.9 \\
Estimated net output at design (nameplate) & $100 \mathrm{MWe}$ \\
Power block design point & \\
Rated cycle conversion efficiency & 0.3774 \\
Design inlet temperature & $391^{\circ} \mathrm{C}$ \\
Design outlet temperature & $293^{\circ} \mathrm{C}$ \\
Fossil backup boiler lower heating value & 0.9 \\
$\quad$ LHV) efficiency & $391{ }^{\circ} \mathrm{C}$ \\
Auxiliary heater outlet set temperature & Minimum backup level \\
Fossil dispatch mode & \\
Plant control & $2 \mathrm{~h}$ \\
Low resource standby period & 0.2 \\
Fraction of thermal power needed for & \\
standby & $0.5 \mathrm{~h}$ \\
Power block startup time & 0.2 \\
Fraction of thermal power needed for startup & $30{ }^{\circ} \mathrm{C}$ \\
Minimum required startup temperature & 1.05 \\
Maximum turbine over design operation & 0.25 \\
Minimum turbine operation & $100 \mathrm{Bar}$ \\
Rankine cycle parameters & 0.02 \\
Boiler operating pressure & Evaporative/air-cooled \\
Steam cycle blowdown fraction & \\
Condenser type & \\
\hline
\end{tabular}

2013). Figure 6 shows the flow of information in the solar field (Kost et al. 2013). Acknowledging the abundance of dust at the site and its negative effect on the solar field performance, the number of times the solar collectors should be cleaned per annum was set at 96 , that is, washing the collectors twice a week.

\section{Power cycle}

To ensure that high efficiency is achieved in the power conversion system, a steam Rankine cycle with superheating and reheating systems was opted for in this study. To assess the performance of the proposed power plant, two different condenser technologies were utilized, these are evaporative (wet) cooling and dry cooling technologies. Table 3 shows the characteristics of the power cycle system as used in this study.

\section{Storage system}

The proposed parabolic trough power plant in this study was designed to constitute of a 2-tank thermal energy storage system. The thermal energy storage system comprises an indirect active storage tank in which Therminol VP-1 that flows in the solar field is stored and a molten salt storage tank. The molten salt storage tank was sized based on the night time electricity demand (peak load design). The energy storage system was with a maximum storage for a period $6 \mathrm{~h}$ in order to avoid oversizing the backup. The properties of the storage system and heat transfer fluid as used in this study are shown in Table 4.

\section{Power plant economic analysis}

The levelized cost of electricity (LCOE) is the main economic metric among others used to compare electricity generating technologies. The LCOE depicts the cost of electricity generation from a specified technology over its lifetime. The LCOE is evaluated on the basis of the net present value approach, technology investment expenses, cash inflows and cash outflows, during the lifetime of the technology are discounted from the reference date (Kost et al. 2013). The LCOE can be evaluated by using the following representation: 
Table 4 Storage system and heat transfer fluid properties

\begin{tabular}{|c|c|}
\hline \multicolumn{2}{|l|}{ Storage system } \\
\hline Parameter & Value \\
\hline Full load hours of thermal energy storage & $6 \mathrm{~h}$ \\
\hline Storage volume & $22,520.9 \mathrm{~m}^{3}$ \\
\hline Thermal energy storage thermal capacity & $1665 \mathrm{MWht}$ \\
\hline Parallel tank pairs & 1 \\
\hline Tank height & $20 \mathrm{~m}$ \\
\hline Tank fluid minimum height & $1 \mathrm{~m}$ \\
\hline Tank diameter & $37.8646 \mathrm{~m}$ \\
\hline Minimum fluid volume & $1126.05 \mathrm{~m}^{3}$ \\
\hline Tank loss coefficient & $0.4 \mathrm{~W} / \mathrm{m}^{2}-\mathrm{K}$ \\
\hline Estimated heat loss & $0.451463 \mathrm{MWt}$ \\
\hline Cold tank heater set point & $250^{\circ} \mathrm{C}$ \\
\hline Hot tank heater set point & $365^{\circ} \mathrm{C}$ \\
\hline Tank heater capacity & $25 \mathrm{MWht}$ \\
\hline Tank heater efficiency & 0.98 \\
\hline Hot/cold side HX approach temperature & $5^{\circ} \mathrm{C}$ \\
\hline Thermal storage exergetic efficiency & 0.966 \\
\hline Initial thermal energy storage fluid temperature & $300^{\circ} \mathrm{C}$ \\
\hline Thermal energy storage fluid density & $1872.49 \mathrm{~kg} / \mathrm{m}^{3}$ \\
\hline Thermal energy storage specific heat & $1.50182 \mathrm{~kJ} / \mathrm{kg}-\mathrm{K}$ \\
\hline \multicolumn{2}{|l|}{ Heat transfer fluid (Hitec solar salt-Nitrate salt ${ }^{*}$ ) } \\
\hline Parameter & Value $\left({ }^{\circ} \mathrm{C}\right)$ \\
\hline Minimum operating temperature & 238 \\
\hline Maximum operating temperature & 593 \\
\hline Freeze point & $\begin{array}{l}238 \text { (crystallization } \\
\text { point) }\end{array}$ \\
\hline
\end{tabular}

*Standard for current tank storage systems

$\mathrm{LCOE}=\frac{I_{0}+\sum_{t=1}^{n} \frac{A_{t}}{(1+i)^{t}}}{\sum_{t=1}^{n} \frac{M_{t, \mathrm{el}}}{(1+i)^{t}}}$

where $\left(I_{0}\right)$ is the investment expenditures in USD $\$,\left(A_{t}\right)$ is the annual total costs in USD $\$$ in year $(t),\left(M_{t, \mathrm{el}}\right)$ is the quantity of electricity produced in the relevant year in $k \mathrm{Wh},(i)$ is the real interest rate in $\%,(n)$ is the economic operational lifetime in years, and $(t)$ is the year in the system lifespan $(1,2, \ldots n)$.

\section{Results and discussion}

\section{Electricity production}

Figure 7 shows the monthly electricity production from the designed power plant with two different cooling systems: dry and wet, and the respective DNI of each month.
It can be noticed that even though the electricity production appears to be similar in March, May and July, the best performances of the power plant were recorded during the month of March, with the production of 38,575.3 MWh and 41,421 MWh using a dry cooling system and an evaporative cooling system, respectively. The highest electricity production was recorded during the month of March mainly because of the high solar irradiation in that month compared to the rest of the months of the year. Furthermore, Fig. 7 shows an interesting variation in the electricity production between the months of June and February even though solar irradiation received is the same. In fact, for almost equal solar irradiation received by the solar field, the electricity production was significantly different between the two months with values reaching 30,322 MW and 31,876 MW for dry and wet cooling systems, respectively, for the month of February and 34,983 MW and 38,918 MW for dry and wet cooling systems, respectively, for the month of June. 
Fig. 7 Monthly electricity production for one year

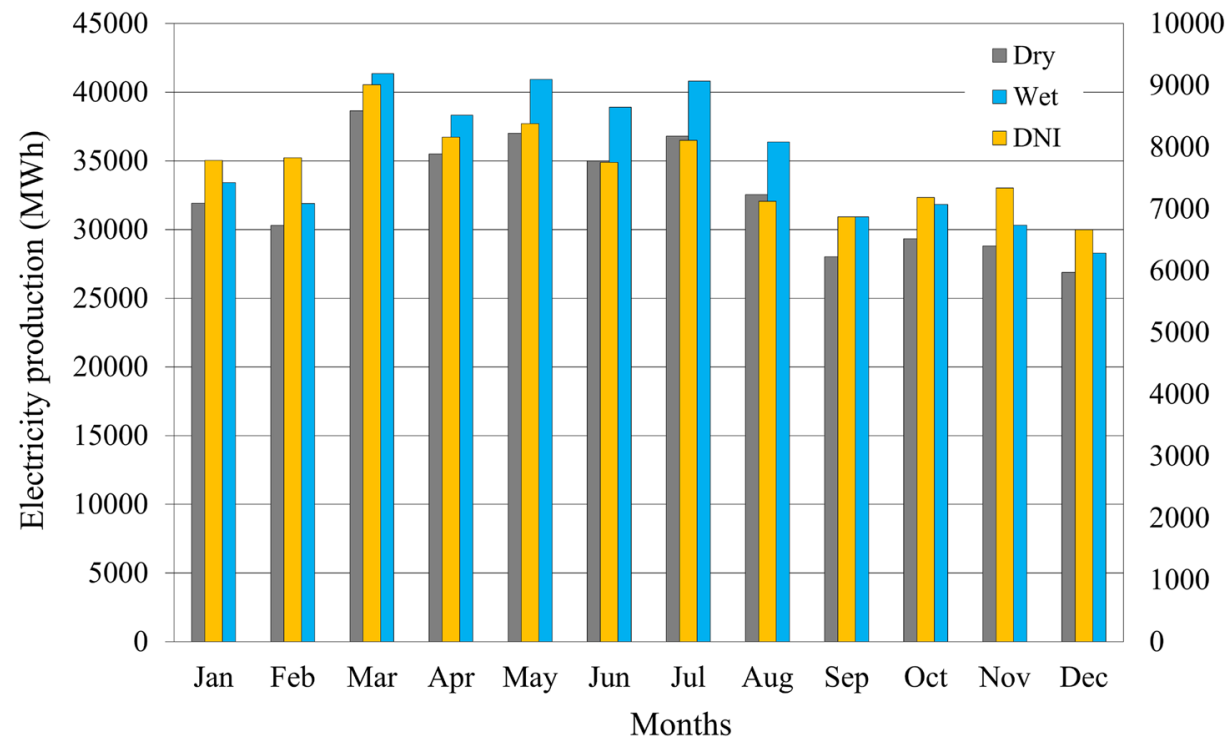

10000

9000

8000

2000

1000

Months

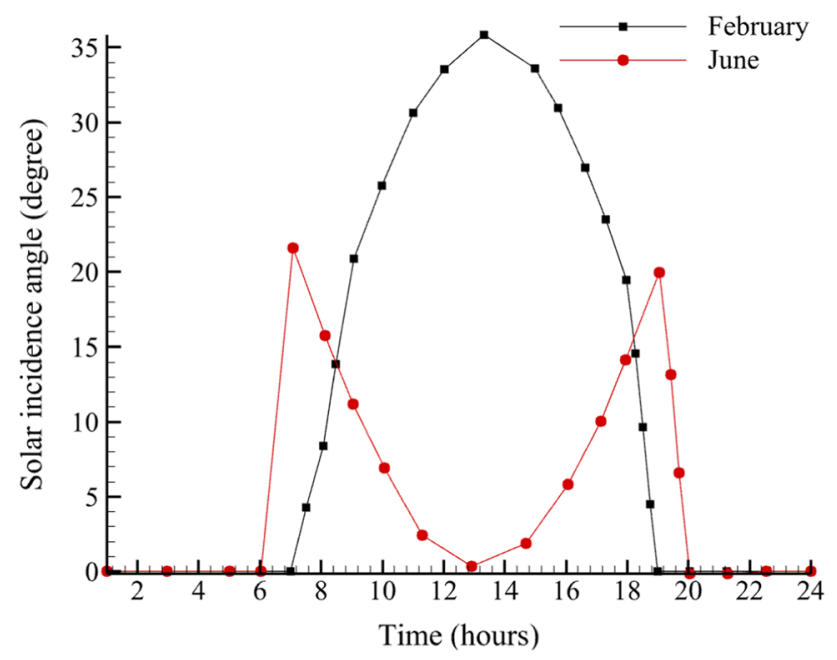

Fig. 8 Solar incidence angle

This discrepancy in the electricity production is due to the weather conditions that are witnessed at the location given that different seasons experienced in these two months.

To further demonstrate the impact of the ambient temperature and solar incidence angle have on the electricity production of the plant shown in Fig. 7, Figs. 8 and 9 show the variations in the solar incidence angles and ambient temperatures, respectively, for the months of February and June. Starting with the solar incidence angle (Fig. 8), acknowledging the fact that the thermal energy absorbed by the solar collector field is directly dependent on to the solar incidence angle, the performance analysis revealed that the power plant would produce more

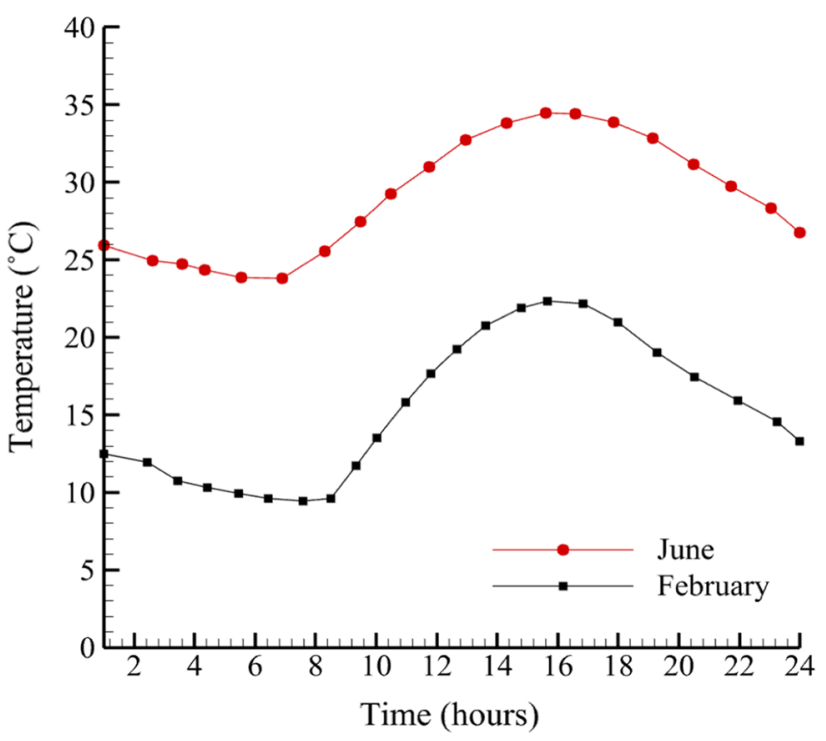

Fig. 9 Dry bulb temperature

electricity in the month of June than February, although the solar irradiation received during February was slightly higher than that of June.

Looking at the effect of the ambient temperature on the power plant productivity, Fig. 9 shows a very high variation in the hourly average ambient temperature between the two selected months. Since heat losses in such power plants depend greatly on the environmental conditions, dry air-cooled power block's efficiency was found to be lower in summer compared to winter. In fact, the dry cooled system's efficiency was found to be $35 \%$ and $31 \%$ for the months of February and June, respectively. On the 
Fig. 10 Ratio of energy produced by wet and dry-cooled power plants

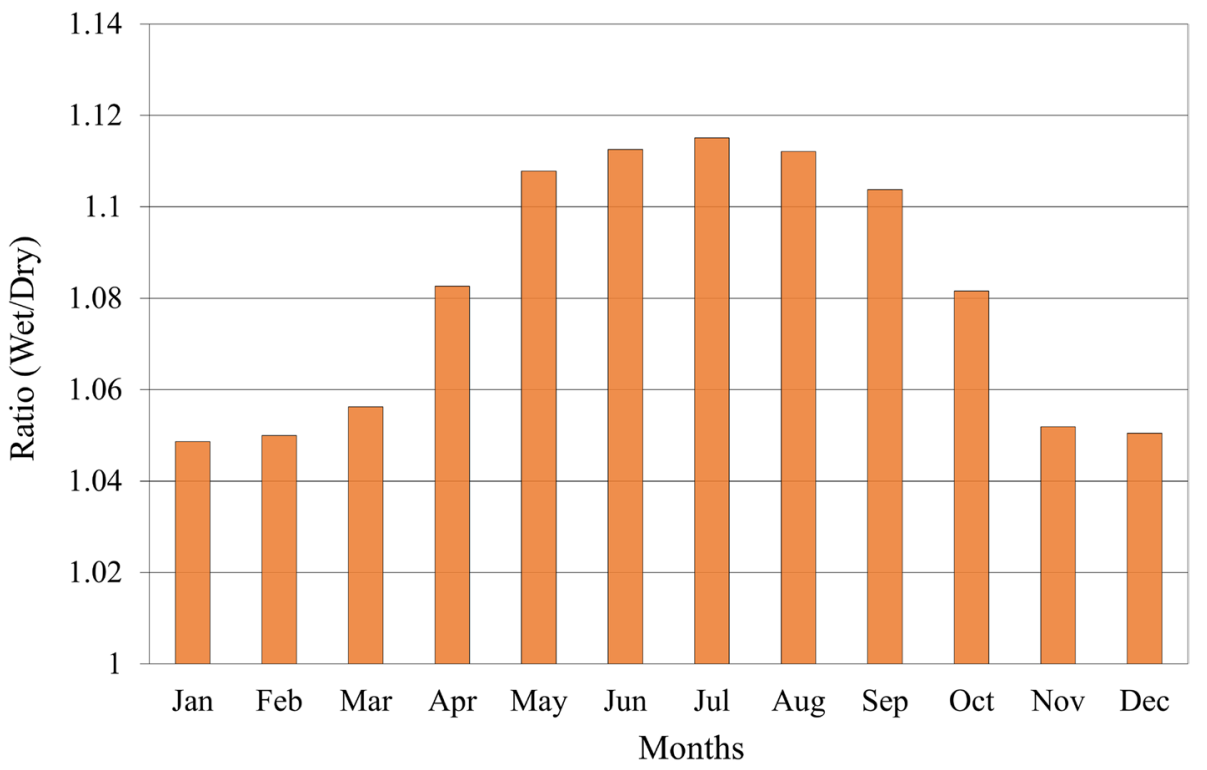

Table 5 Power plant solar efficiency and capacity factor

\begin{tabular}{lll}
\hline & Solar efficiency (\%) & $\begin{array}{l}\text { Capacity } \\
\text { factor } \\
(\%)\end{array}$ \\
\hline Dry cooling & 14.5 & 44.6 \\
Evaporative cooling & 15.3 & 48.3 \\
\hline
\end{tabular}

other hand, when the power plant is using evaporative cooling system, the efficiency did not vary much with the variation in the ambient temperature. The recorded efficiencies for the months of February and June were $35 \%$ and $34 \%$, respectively.

Figure 10 shows the ratio of the electricity production, which is described as the amount of electricity produced by wet cooled system divided by electricity produced by dry cooled system. It can be noticed that during the summer season (May-September), the ratio is higher compared to the other months of the year. For instance, during the month of June where the ambient temperature was high, as shown in Fig. 9, it could be the cause for the high ratio value that is almost double the ratio value for the month of February. This difference in electricity production can be attributed to the influence that weather parameters such as the ambient temperature have on the power plant since the ambient temperature directly affects the efficiency of dry cooled systems.

It is clearly evident from Fig. 7 that for all the months of the year, the electricity production from the proposed power plant with an evaporative cooling system is higher than for the case with a dry cooling system. To quantify the difference, the solar efficiencies of the two

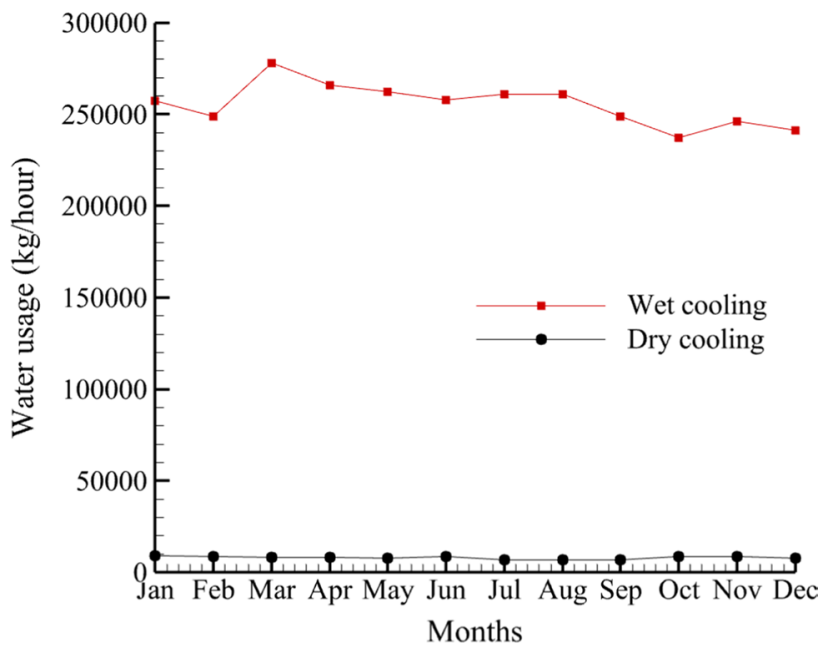

Fig. 11 Power plant water usage

systems and the capacity factors of each power plant were calculated. The solar efficiency of the power plant using two different cooling systems was calculated as follows:

$\varepsilon_{s}=\frac{\text { Actual output of the plant }}{\text { Total incident irradiation }} * 100$

The capacity factor, on the other hand, is defined as the ratio of the actual output during a specific period of time over the amount of energy produced from the power plant when it is working at full capacity. The capacity factor was calculated as follows: 
$\mathrm{CF}=\frac{W_{a}}{P_{\text {out }} * 8760}$

where $\left(W_{a}\right)$ is the annual electric energy output and $\left(P_{\text {out }}\right)$ is the rated output power for one hour. Based on Table 5, the calculated values of the solar efficiency and capacity factor show that the overall performance of the wet cooled power plant surpasses the performance of the dry air cooled plant, which is mainly due to the weather conditions at the considered location.

\section{Water usage}

Figure 11 shows the quantity of water consumed by the power plant for both cases: wet and dry cooled power block. In general, the water usage in the parabolic trough power plant is divided into three main parts; parabolic trough washing, steam generation, and the cooling system. As it is revealed in Fig. 11, a large difference exists between the two cooling systems, the power plant with the evaporative cooling system consumes about 14 times more water than the one with the air-cooled system. This is because the power plant with the dry air cooling system only uses water for steam generation and the washing of the mirrors. The highest amount of water consumption was observed during the months when the solar irradiation was highest (high electricity production), particularly in the month of March where it reached $277,777.9 \mathrm{~kg} /$ hour and $8,831.98 \mathrm{~kg} /$ hour for the evaporative and aircooled systems, respectively. Moreover, by setting the amount of water needed for washing the mirrors to 0.7 L for each $1 \mathrm{~m}^{2}$ of reflective area, both power plants use about $84,000 \mathrm{~m}^{3}$ of water annually. However, this amount of water consumption only represents about $5 \%$ and $60 \%$ of the total water consumption for the wet cooled and air

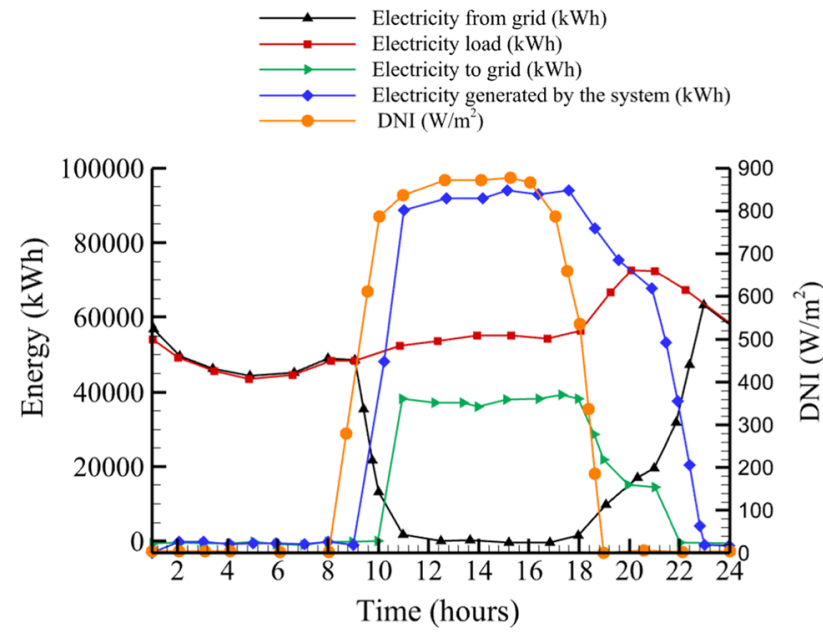

Fig. 12 January electricity supply dry cooled systems, respectively, that is shown in Fig. 11. Thus, this indicates that the major component leading to the higher water consumption in the power plant is the cooling system.

Due to the enormous quantity of water used in the power plant with the wet cooling condenser, this case is could create more challenges for the developers in search for the adequate water supply to sustain the plant's demands. Based on electricity production of the considered cases, there is relatively a minor difference in electricity production between the power plant with the wet cooling system and the one with the dry air cooling system. Thus, because of the water scarcity in the region of Tamanrasset, the rest of this study only discusses and examines the power plant with the dry cooling system.

\section{Load and electricity production}

Figure 12 depicts the average daily electricity load demand and electricity supply for the city of Tamanrasset for the month of January with the incorporation of the proposed power plant with the dry cooling system. Simulation results show the role that could be played by incorporating the PTC power plant in supporting the existing grid to satisfy the electricity needs of the considered city. Having discussed earlier the effect of ambient temperature on the power plant productivity, it is worth to mention that the month of January (Winter) was selected because of its low recorded ambient temperature values. In terms of electricity supply and consumption, one can see that while consuming a minor amount of energy ( 8670 $\mathrm{kWh}$ shown in the graph by negative values), the power

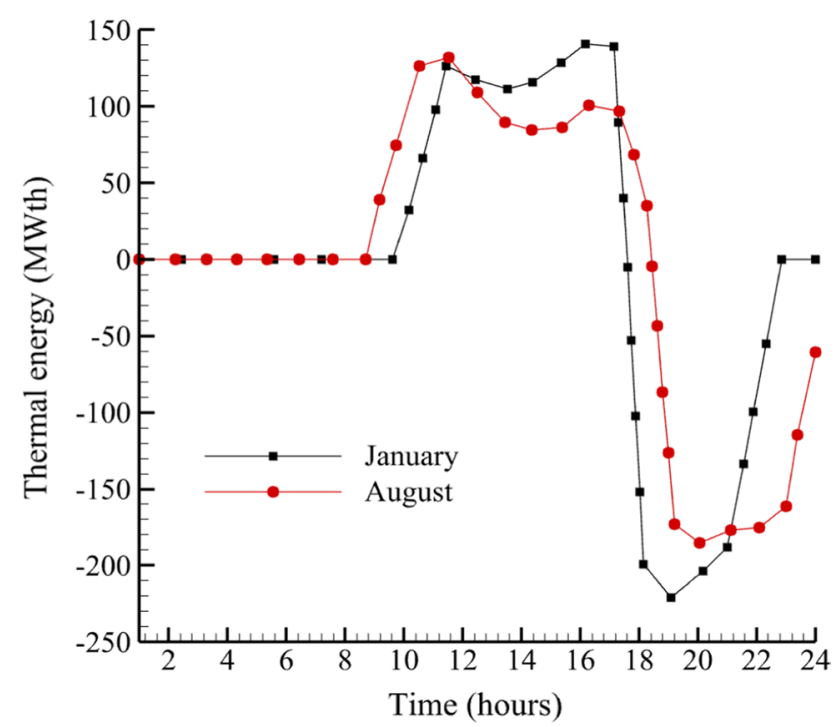

Fig. 13 Charging and discharging of thermal energy storage during January and August 


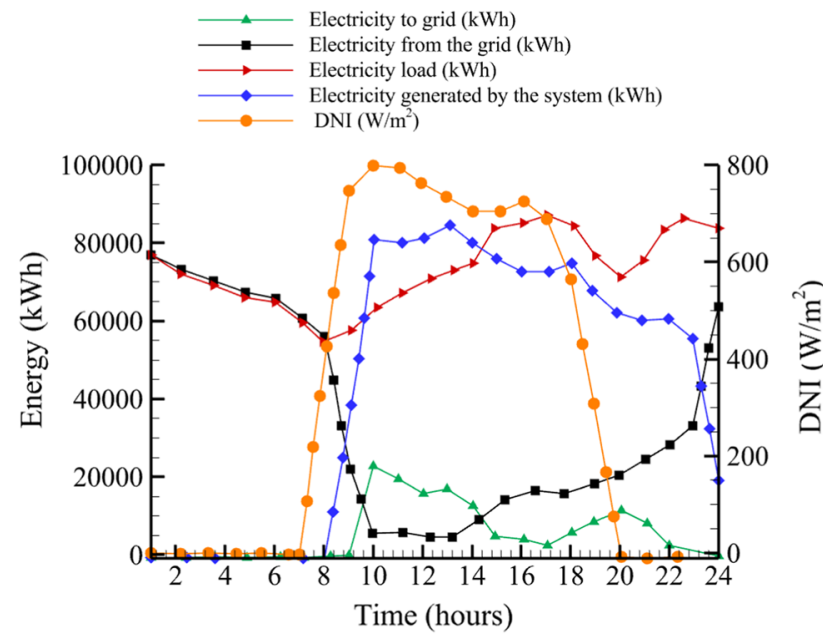

Fig. 14 August electricity supply

plant was capable of providing up to $1,032,785.5 \mathrm{kWh}$ per day. Figure 12 shows that the power plant consumes some electricity from the grid during the night time to keep the heat transfer fluid's temperature above the freezing point in the storage tanks, receivers and in other services related to the power plant's operation. During the daytime (from 10:00 am to 18:00 pm), the power plant is able to generate sufficient electricity to supply the city's needs with the surplus electricity to feed to the main grid as well as the surplus thermal energy to feed to the storage tank. After 19:00 pm when the solar irradiation becomes weak, the energy storage tank maintains the electricity supply from the plant till 23:00 pm. However, from 23:00 pm to 9:00 am, the grid supplies the entire electricity needs of the city. Considering all the above, it is important to highlight that even though solar energy is intermittent, based on Fig. 12, the PTC power plant can supply $78 \%$ of the electricity demand, while the grid supplies the remaining $22 \%$ of the city on a daily basis.

Referring to the thermal energy storage's average daily charging and discharging periods for the month of January (Fig. 13), and given that the energy storage tank is designed with a 1665 MWth capacity, it was established that tank can only be charged to about 930 MWth. This is due to the low potential of solar irradiation during January as well as the nature of the city's load. It can be noticed that when the solar irradiation starts to decrease such that the power plant is unable to supply enough electricity to satisfy the load (at 17:00 pm), the energy storage starts to supply the power block with the thermal energy stored in order to generate enough electricity to meet the city's demand. Between 18:00 and 22:00 pm, the thermal energy storage and grid supply $91 \%$ and $9 \%$ of the total electricity needs of the city, respectively.
On the other hand, Fig. 14 shows the electricity load and the electricity supply for the city of Tamanrasset during the month of August (extreme high temperature). As discussed earlier, the electricity load is higher in summer than in winter, therefore, the electricity balance simulation results show that the power plant could be able to cover only $60 \%$ of the total daily electricity demand of the city, and the national grid would supply the remaining $40 \%$. Furthermore, the power plant was found to be able to supply the electricity needs of the city for only $5 \mathrm{~h}$ per day: from 9:00 am to 13:00 pm. The grid supplied electricity to the system during the whole day, during which the power plant was sometimes also supplying electricity to the grid. The electricity produced by the power plant in August was found to be greater than that produced in January, with a notable surplus of almost $27,000 \mathrm{kWh}$. This is due to the number of daylight hours: $12 \mathrm{~h}$ for August compared to $10 \mathrm{~h}$ for January. Furthermore, another factor that could have influenced the recorded higher electricity production during the month of August is the ambient temperature. The maximum recorded ambient temperature in January was approximately $20^{\circ} \mathrm{C}$, while August registered a minimum temperature of $25^{\circ} \mathrm{C}$, with a peak of $35^{\circ} \mathrm{C}$. These weather conditions led to less heat losses to the ambient air which decreases the energy consumed by the power plant.

Referring to the thermal energy storage's average daily charging and discharging periods for the month of August (Fig. 13), during the day, in the presence of high solar irradiation, $950 \mathrm{MW}$ th of thermal energy was supplied by the plant to the storage system during the month of August. Late in the day when solar irradiation received is low, the generated electricity is not enough to meet the electricity demand. Therefore, the

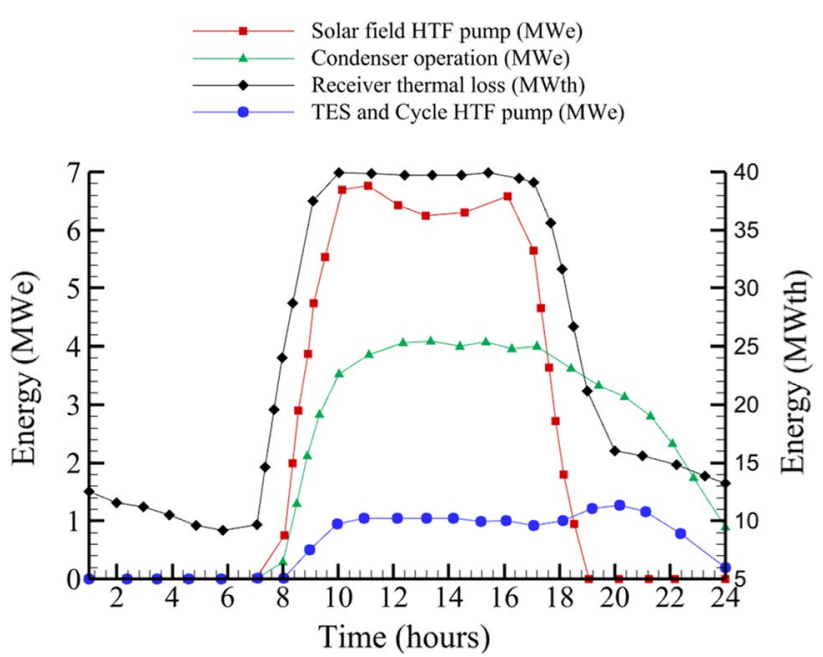

Fig. 15 Parasitic losses of the system 
storage tank supplies thermal energy to the power block system in order to increase the electricity production to cover the city's electricity needs. Overall, the electricity generated by using the thermal energy stored in the tank covers $64 \%$ of the electricity demand, while the grid supplies the remaining $36 \%$ of the electricity to meet the city's demand. Notably, after midnight the energy storage tank does not have any contribution to the electricity supply to the city because of its limited storage capacity.

\section{Energy losses}

Figure 15 shows the different energy losses that occur throughout the operation of the power plant. During the power plant's normal operation, only the energy losses due to the solar field HTF pump, condenser operation and receiver thermal losses were significant. This is due to the HTF pumps in the solar field working only in the morning when solar irradiation is available. However, for the condenser, the electricity consumption stays almost constant during the peak electricity production reaching about $4 \mathrm{MW}$, while at night it decreases with the decrease in the electricity production. Thus, the condenser electricity consumption is directly proportional to the electricity production by the power plant. The pump that circulates the molten salt in the thermal energy storage cycle consumes around $1 \mathrm{MWe}$ for charging the energy storage tank during the day, and consumption increases slightly to about $1.2 \mathrm{MWe}$ at night when the energy storage tank is discharging. These losses are identified as parasitic losses because they refer to the electricity consumed by the power plant itself. Thermal losses were found to be mainly due to receiver losses, which amount to about $40 \mathrm{MW}$ th during the peak hours and $15 \mathrm{MWth}$ when the solar irradiation is low.

\section{Cost analysis}

To calculate the LCOE, the parameters shown in Table 6 were considered for the evaluation of the initial cost of investment. In addition to the initial costs, operational and maintenance costs were taken as approximately equal to $1 \%$ of the initial investment. Insurance costs and tax rates were also taken into consideration. The interest rate of $3.75 \%$ used in this study was obtained
Table 6 Cost assumptions for simulation

Fig. 16 Cash flow of the investment

\begin{tabular}{lll}
\hline Parameter & & Cost (labor taken into account) \\
\hline Land and site improvement & $954,840 \mathrm{~m}^{2}$ & $15.11 \mathrm{USD} \$ \mathrm{~m}^{2}$ \\
Solar field & $954,840 \mathrm{~m}^{2}$ & $377.69 \mathrm{USD} \$ \mathrm{~m}^{2}$ \\
Heat transfer fluid system & $954,840 \mathrm{~m}^{2}$ & $37.77 \mathrm{USD} \$ \mathrm{~m}^{2}$ \\
Storage & $1,665 \mathrm{MW}_{\text {th }}$ & $52.88 \mathrm{USD} \$ \mathrm{~kW}$ \\
Power plant capacity & $110 \mathrm{MW}_{\mathrm{e}}$ & $664.73 \mathrm{USD} \$ \mathrm{~kW}$ \\
Contingency & Approx. $(10 \%)$ & $46,475,308.08 \mathrm{USD} \$$ \\
Inflation rate & 4.85 & \\
Interest rate & 3.75 & \\
Initial cost & $511,228,388.91 \mathrm{USD} \$$ \\
\hline
\end{tabular}




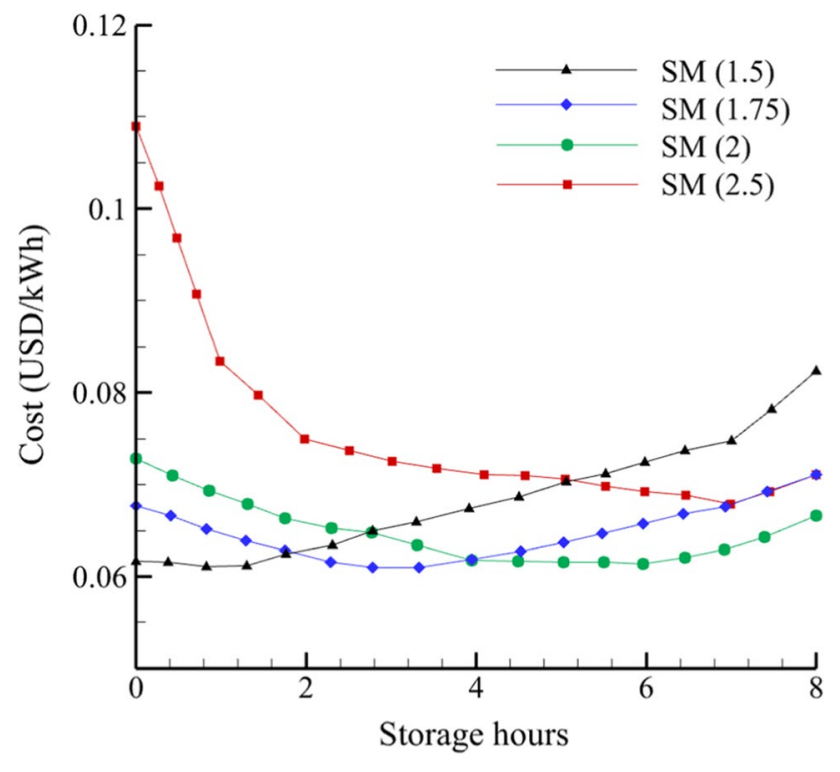

Fig. 17 LCOE as a function of storage hours and solar multiple

from the Trading Economics website (Trading Economics 2019), and the inflation rate was obtained from the Algerian Ministry of Finance's website (Algerian Ministry of Finance 2019). The power plant was designed for a lifespan of 25 years. The economic analysis results show that the LCOE is lower than international pricing, with a value of $0.062 \mathrm{USD} \$ / \mathrm{kWh}$. This low value of the LCOE is due to the high resource availability of solar energy in Tamanrasset, that enables high electricity production by the proposed power plant. The payback period was calculated to be 8.78 years. The feed in tariff was taken from the Algerian program for renewable energies, with a value of $300 \%$, which gives a selling price of 0.09 USD $\$ / \mathrm{kWh}$ for the whole lifespan, factored by the inflation rate (Meyer-Renschhausen 2013). The benefit-cost ratio was therefore found to be 1.73 , meaning that the project's profits exceed its expenses.

Figure 16 shows the cash flow analysis for the designed power plant during the entire lifespan of 25 years. The cash flow analysis depicts precisely how money is transferred into and out of the project. It can be noticed that, for the first seven years, the cash flow is negative (the project's liquid assets are negative). However, starting from the eighth year of operation, the cash flow becomes positive, indicating that the liquid assets are increasing, enabling reinvestment, creating benefits for the owners, as well as paying other expenses.

A sensitivity analysis on how the LCOE is affected by changing the solar multiple and the storage hours is provided in Fig. 17. For each solar multiple, there is an optimum number of thermal energy storage hours that gives the lowest LCOE. The lowest LCOE of 0.061 USD $\$ / \mathrm{kWh}$ was found for a system with a solar multiple

Fig. $18 \mathrm{CO}_{2}$ emissions avoided

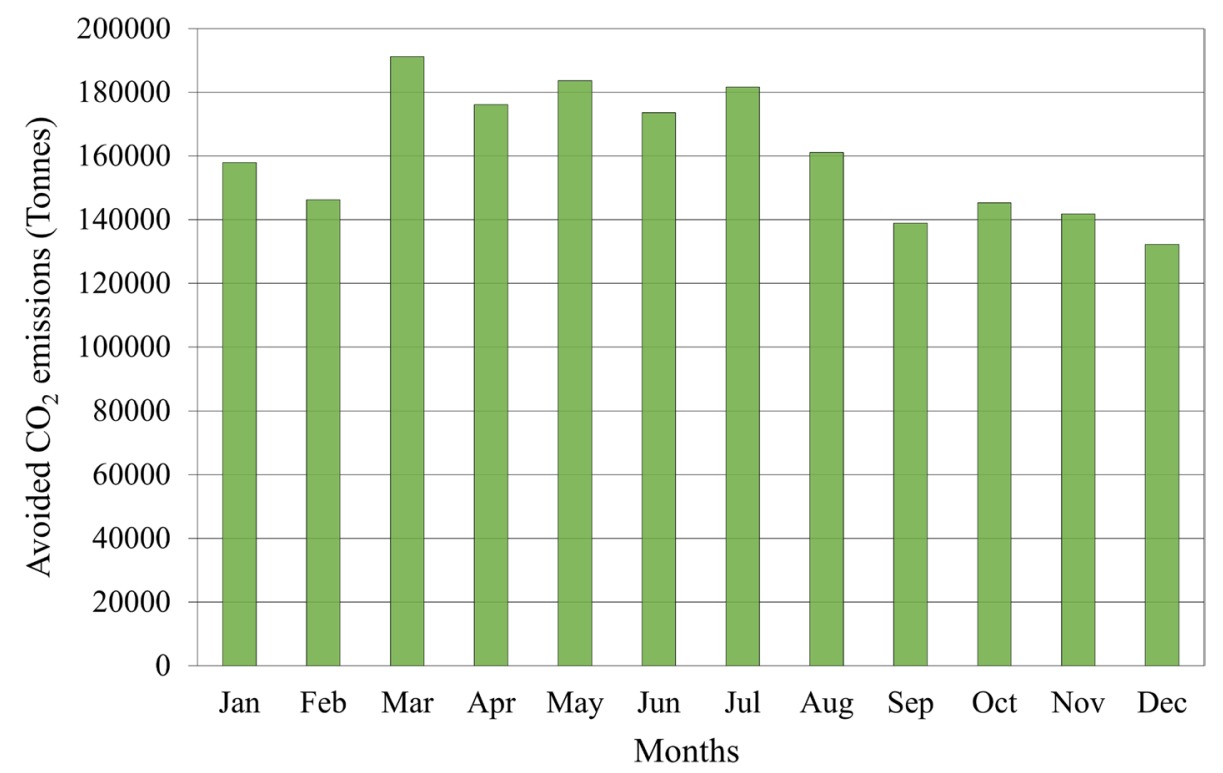


of 1.75 and a 3 -h energy storage. This shows the importance of power plant optimization prior to any investment. Moreover, these parameters are only valid for the selected location as well as the technology.

\section{PTC power plant emissions}

In order to estimate the environmental benefit of the project in terms of $\mathrm{CO}_{2}$ emissions, a comparison was made between a combined cycle power plant using natural gas (dominant technology for electricity production in Algeria) as fuel and the simulated power plant (PTC). On average, the amount of $\mathrm{CO}_{2}$ emitted by a combined cycle power plant using natural gas is about $400 \mathrm{~kg} / \mathrm{MWh}$ (IEA ETSAP 2010). For the same amount of energy generated over one year by (PTC), a combined cycle power plant can produce almost 2 million tons of $\mathrm{CO}_{2}$ per year (Fig. 18). The progressively escalating concentrations of $\mathrm{CO}_{2}$ emissions in the atmosphere associated with fossil fuels are bringing about irretrievable adverse impacts on the Earth in the form of global warming and climate change (Solomon et al. 2009), leading to a rise in temperatures which in turn can cause a rise in sea level, dryseason rainfall reductions and severe droughts in some parts of the world, extreme weather conditions, the loss of ecosystems, and potentially hazardous health effects (Jacobson 2008; Abdul-Wahab et al. 2017). Considering the energy transition toward clean energy, this clearly shows that parabolic trough systems are a better option for electricity generation since they have no harmful gaseous emissions during their operational lifetime.

\section{Conclusion}

The present study was conducted to assess and model a $100 \mathrm{MW}$ parabolic trough-based solar thermal power plant using two different cooling systems: dry and evaporative condensers. The power plant was designed with a solar multiple of two, generating excess energy that would be stored by thermal energy storage using the globally applied technology of indirect two-tank (cold/hot) thermal storage using molten salt. Thereafter, a feasibility study was performed to ascertain whether such a project could be viable in Algeria under the climatic conditions prevailing in Tamanrasset and under the law governing renewable energies in Algeria. By comparing the plant's electricity production to the city's real load demand, it was found out that the power plant would be able to cover $78 \%$ and $60 \%$ of the city's electricity needs during winter and summer, respectively. The biggest share of energy losses in the power plant was found to be in the form of parasitic losses, that is, in the power plant heat transfer pumps and in the receivers in the form of thermal losses. A cost analysis of the power plant was performed, and the results showed that the levelized cost of electricity (LOCE) is about $0.062 \mathrm{USD} \$ / \mathrm{kWh}$, a payback period of 8.78 years, and a benefit-cost ratio of 1.73 , revealing that the project is feasible under the economic conditions imposed by the Algerian government. Furthermore, an environmental impact analysis of the power plant was conducted and showed that the solar power plant is able to avoid carbon dioxide gas emissions of 2 million tons of $\mathrm{CO}_{2}$ per year in comparison with a conventional generation system. The development of such utility-scale parabolic trough-based solar thermal power plants will be a major milestone in the renewable energy sector in Algeria, not only to add a new capacity but also to increase energy security and address the environmental concerns. The findings of this assessment are of high significance and can encourage policymakers, investors as well as the actors in the field of solar energy to establish more investments in Algeria. This, in turn, will generate employment opportunities that will alleviate poverty and provide a visionary approach towards achieving a cleaner, more sustainable energy future not only for Algerians, but also for others around the world considering that Algeria has the potential to become a major exporter of renewable energy in the world.

Acknowledgements The authors would like to thank the African Union and the Pan African University Institute of Water and Energy Sciences for the financial support provided to conduct this research.

\section{Declarations}

Conflicts of interest The authors declare that there is no conflict of interest regarding the publication of this article.

\section{References}

Abbas M, Boumeddane B, Said N, Chikouche A (2009) Techno economic evaluation of solar Dish Stirling system for stand alone electricity generation in Algeria. J Eng Appl Sci 4(4):258-267

Abbas M, Boumeddane B, Said N, Chikouche A (2011) Dish Stirling technology: a $100 \mathrm{MW}$ solar power plant using hydrogen for Algeria. Int J Hydrog Energy 36(7):4305-4314

Abbas M, Merzouk NK, Belgroun Z, Aburidah H (2013a) Parametric study of the installation of a solar power tower plant under Saharan climate of Algeria: case study of Tamanrasset. In: Proceedings of the First International Conference on Nanoelectronics, Communications and Renewable Energy (ICNCRE 2013), pp 357-362

Abbas M, Belgroun Z, Aburidah H, Merzouk NK (2013b) Assessment of a solar parabolic trough power plant for electricity generation under Mediterranean and arid climate conditions in Algeria. Energy Proc 42:93-102 
Abbas M, Belgroun Z, Merzouk NK (2014) Techno economic performances of a dry cooling solar power tower plant under Algerian climate. Int J Energy Technol Policy 10(2):109-124

Abdul-Wahab S, Al-Rawas G, Ali S, Fadlallah S, Al-Dhamri H (2017) Atmospheric dispersion modeling of $\mathrm{CO}_{2}$ emissions from a cement plant's sources. Clean Technol Environ Policy 19(6):1621-1638

Agence Nationale de Développement de l'Investissement (ANDI), (2013) Wilaya fé Tamanerasset. http://www.andi.dz/index.php/ fr/86-guichets-de-1-andi/124-gud-tamanrasset?date=2014-5-1. Accessed 7 Jan 2019

Agyekum EB, Velkin VI (2020) Optimization and techno-economic assessment of Concentrated Solar Power (CSP) in South-Western Africa: a case study on Ghana. Sustain Energy Technol Assess 40:100763

Algerian Ministry of Finance (2019) Taux d'inflation. http://www. mf.gov.dz/index.php. Accessed 6 July 2019

Aseri TK, Sharma C, Kandpal TC (2020) Estimating capital cost of parabolic trough collector based concentrating solar power plants for financial appraisal: approaches and a case study for India. Renew Energy 156:1117-1131

Baharoon DA, Rahman HA, Omar WZW, Fadhl SO (2015) Historical development of concentrating solar power technologies to generate clean electricity efficiently-a review. Renew Sustain Energy Rev 41:996-1027

Bhuiyan N, Ullah W, Islam R, Ahmed T, Mohammad N (2020) Performance optimisation of parabolic trough solar thermal power plants-a case study in Bangladesh. Int J Sustain Energy 39(2):113-131

Boretti A, Castelletto S, Al-Kouz W, Nayfeh J (2020) Enclosed trough solar thermal power plant with thermal energy storage and saltwater condenser in Al Khobar, Kingdom of Saudi Arabia. Renew Energy Focus 35:132-147

Boudries R, Dizene R (2008) Potentialities of hydrogen production in Algeria. Int J Hydrog Energy 33(17):4476-4487

Boukelia T, Mecibah MS (2013) Parabolic trough solar thermal power plant: potential, and projects development in Algeria. Renew Sustain Energy Rev 21:288-297

Boukelia TE, Mecibah MS, Kumar BN, Reddy KS (2015) Optimization, selection and feasibility study of solar parabolic trough power plants for Algerian conditions. Energy Convers Manag 101:450-459

Chukwubuikem C, Komla F (2015) An economic assessment of the concentrated solar power with national energy regulator of South African Feed-in Tariff scheme. J Energy Power Sources 2(4):137-143

Desai NB, Bandyopadhyay S (2016) Thermo-economic comparisons between solar steam Rankine and organic Rankine cycles. Appl Therm Eng 105:862-875

IEA ETSAP (2010) Technology Brief E02-Gas-Fired Power. International Energy Agency (IEA). https://iea-etsap.org/E-TechDS/ PDF/E02-gas_fired_power-GS-AD-gct_FINAL.pdf

Fadlallah SO, Benhadji Serradj DE (2020) Determination of the optimal solar photovoltaic (PV) system for Sudan. Sol Energy 208:800-813

Geyer M, Lüpfert E, Osuna R, Esteban A, Schiel W, Schweitzer A, Zarza E, Nava P, Langenkamp J, Mandelberg E (2002) EUROTROUGH-Parabolic trough collector developed for cost efficient solar power generation. In: 11th international symposium on concentrating solar power and chemical energy technologies, Zurich, Switzerland, pp 1-7
GlobalPetrolPrices.com (2020) Sudan Diesel prices. Global Petrol Prices. Retrieved from https://www.globalpetrolprices.com/ Sudan/diesel_prices/. Accessed Feb 2021

Goswami DY (2015) Principles of solar engineering, 3rd edn. CRC Press, New York

Ikhlef K, Larbi S (2020) Techno-economic optimization for implantation of parabolic trough power plant: case study of Algeria. J Renew Sustain Energy 12(6):063704

Iliev D (2011) Discrepancies in solar irradiation data for Stockholm and Athens (Masters Dissertation), Dalarna University

IndexMundi (2021) CIA World Factbook. http://www.indexmundi. com/g/r.aspx? $\mathrm{v}=81000$. Accessed Feb 2021

Jacobson MZ (2008) On the causal link between carbon dioxide and air pollution mortality. Geophys Res Lett 35(3):1-5

Kabir E, Kumar P, Kumar S, Adelodun AA, Kim KH (2018) Solar energy: potential and future prospects. Renew Sustain Energy Rev 82:894-900

Kaltschmitt M, Streicher W, Wiese A (2007) Renewable energytechnology, economics and environment. Springer-Verlag Berlin Heidelberg, Berlin, Germany

Kariuki KS (2012) Technical and economic analysis of parabolic trough concentrating solar thermal power plant (Doctoral dissertation), University of Cape Town

Kost C, Mayer JN, Thomsen J, Hartmann N, Senkpiel C, Philipps S, Nold S, Lude S, Saad N, Schlegl T (2013) Levelized cost of electricity renewable energy technologies. Freiburg, Germany: Fraunhofer Institute for Solar Energy Systems ISE. https:// www.ise.fraunhofer.de/content/dam/ise/en/documents/publi cations/studies/Fraunhofer-ISE_LCOE_Renewable_Energy_ technologies.pdf

Liu H, Zhai R, Patchigolla K, Turner P, Yang Y (2021) Off-design thermodynamic performances of a combined solar tower and parabolic trough aided coal-fired power plant. Appl Therm Eng 183:116199

Lopes T, Fasquelle T, Silva HG (2021) Pressure drops, heat transfer coefficient, costs and power block design for direct storage parabolic trough power plants running molten salts. Renew Energy 163:530-543

Meyer-Renschhausen M (2013) Evaluation of feed-in tariff-schemes in African countries. J Energy South Afr 24(1):56-66

Mihoub S, Chermiti A, Beltagy H (2017) Methodology of determining the optimum performances of future concentrating solar thermal power plants in Algeria. Energy 122:801-810

Pina EA, Lozano MA, Serra LM, Hernández A, Lázaro A (2021) Design and thermoeconomic analysis of a solar parabolic trough-ORC-Biomass cooling plant for a commercial center. Sol Energy 215:92-107

Remun J, Müller S, Kunz S, Schilter C (2015) Meteonorm-Global meteorological database (Version 7). http://www.energiehaus. es/wp-content/uploads/2015/06/manual-usuario-part-1-meteo norm.pdf

Schnatbaum L (2009) Solar thermal power plants. Eur Phys J Spec Top 176(1):127-140

Sinha S, Chandel SS (2014) Review of software tools for hybrid renewable energy systems. Renew Sustain Energy Rev 32:192-205

Solar S (2013) SCHOTT PTR®70 Receivers. Technical Data Sheet, Mainz

Solomon S, Plattner GK, Knutti R, Friedlingstein P (2009) Irreversible climate change due to carbon dioxide emissions. Proc Natl Acad Sci 106(6):1704-1709 
Stambouli AB, Khiat Z, Flazi S, Kitamura Y (2012) A review on the renewable energy development in Algeria: current perspective, energy scenario and sustainability issues. Renew Sustain Energy Rev 16(7):4445-4460

Tamir K (2011) Identifying and addressing drivers and barriers to renewable energy development in the rural electrification of Mongolia, Master of Science dissertation, Murdoch University, Australia

Trading Economics (2019) Algeria discount rate. http://www.tradi ngeconomics.com/algeria/interest-rate. Accessed 15 July 2019

U.S. Energy Information Administration (EIA) (2021) Petroleum and other liquids: spot prices. http://www.eia.gov/dnav/pet/pet_ pri_spt_s1_d.htm. Accessed Feb 2021

Ummadisingu A, Soni MS (2011) Concentrating solar power-technology, potential and policy in India. Renew Sustain Energy Rev 15(9):5169-5175

Uzair M (2018) Wind induced heat losses from solar dish-receiver systems. Doctoral dissertation, Auckland University of Technology, Auckland, New Zealand
Wagner MJ, Gilman P (2011) Technical manual for the SAM physical trough model (No. NREL/TP-5500-51825). National Renewable Energy Lab (NREL), Colorado, United States

Wu SY, Xiao L, Cao Y, Li YR (2010) Convection heat loss from cavity receiver in parabolic dish solar thermal power system: a review. Sol Energy 84(8):1342-1355

Yaiche MR, Bouhanik A, Bekkouche SMA, Malek A, Benouaz T (2014) Revised solar maps of Algeria based on sunshine duration. Energy Convers Manag 82:114-123

Yoshino N, Taghizadeh-Hesary F, Otsuka M (2021) Covid-19 and optimal portfolio selection for investment in sustainable development goals. Finance Res Lett 38:101695 